\title{
Mutual Effects between Innovation Commitment and Exports: Evidence from the Owner-Manager in Colombia
}

\author{
Izaias Martins', Eduardo Goméz-Araujo²,YancyVaillant ${ }^{3}$
}

\begin{abstract}
Latin America and the Caribbean is recognized as a region of entrepreneurs, as evidenced by the high amount of ventures per capita; however, just a few number of companies export and most of them show a weak growth and little innovation. Using information from the GEM database - Colombia 2010 and 2011 , this study investigates the mutual effects between the owner-manager's commitment to innovation and the export behavior of companies. Logistic and Ordinal regression models are used to test the proposed hypotheses in this study.

The main findings of this study suggest that the owner-manager's commitment to innovation is an important booster for exports, as well as for increasing sales abroad. Furthermore, the results suggest that the export propensity, in turn, increases the likelihood of involvement of owner-managers to innovate in Colombia.
\end{abstract}

Keywords: innovation; export behavior; owner-manager commitment; gem-colombia

\footnotetext{
'Universidad EAFIT, School of Management, Carrera 49 7Sur 50, Bloque 26, Medellin - Colombia. e-mail: imartins@eafit.edu.co ${ }^{2}$ Universidad del Norte, School of Management, Km 5 Vía a Puerto Colombia. Edificio Álvaro Jaramillo, Barranquilla - Colombia. ${ }^{3}$ ESC-Rennes School of Business, 2, rue Robert d'Arbrissel - CS76522. 35065 Rennes - France.
} 


\section{Introduction}

Latin America and the Caribbean (LAC), despite of being considered as a region of entrepreneurs and that it has enjoyed an important export activity during the period of 2004-2009, faces weaknesses that difficult the growth and internationalization of businesses in the region. In this sense, the major weakness is the lack of innovation. The reduced level of investment, both public and private in R\&D and the little amount of registered patents per companies from LAC show in an indirect way the low intensity and quality of the innovation in the region (Lederman, et. al., 2014). The result of this, is a set of companies offering products and services with little emphasis on innovation and with a moderate added value (Amorós and Cristi, 2008), making it difficult to compete in the international market (Salazar, et. al., 20I4).

For that reason, studies examining the relationship between innovation capability and export behavior in the LAC context are welcome. To include a country like Colombia into this study is relevant because this country is one of the largest economies of the region and it leads the propensity for creation of new businesses, according to surveys in Latin America (GEM - Colombia, 20I2).

Considering an academic perspective, researches during the last decade has resulted in several evidences about the relation between innovation and export behavior (e.g., Caldera, 2010; Cassiman and Golovko, 201 I; Kirbach and Schmiedeberg, 2008; Lachenmaier and Wobmann, 2006), and still, the complementarity that represents the innovation and the export performance for the firm's growth (Golovko and Valentine, 20I I). However, in previous researches the core of study has been the organization and not the individual. In this sense, the analysis by considering the human factor in innovation is essential because innovation depends on people who are able to generate and apply knowledge and ideas in the workplace and in society at large (Schaaper, 2014). Also, previous research has usually had a transversal feature (considering just one year in the analysis), and with some exceptions, they explore just one causal direction of the innovation-export relationship. Equally important, in most of the previous studies, the different innovation dimensions and its effects on export behavior have not been explored separately. Additionally, while it is broadly accepted that innovation contributes to business development (SanchézSellero, et. al., 20I4), there are relatively few studies about the background and the driving forces of the innovative capability (Hult, et. al., 2004).
According to the Resources and Capabilities-Based Theory (Barney, I991; Teece, et. al., 1997), as well as the Learning Theory (Cohen and Levinthal, 1990; Lane and Lubatkin, 1998), an analysis which considers the mutual relationship between the owner-manager's commitment to innovation and the export behavior of the company, is suggested. Consequently, this research aims to provide empirical evidences that support the comprehension on this phenomenon in the region, and which contributes to both the academia and policy makers.

This article is organized with the following structure: the second section shows the theoretical framework, with a brief description of previous studies and the proposed hypothesis; the third section specifies the research methodology and describes the database; the fourth section presents the estimation of results; and the final section provides a discussion about the findings and conclusions.

\section{Theoretical Framework, Previous Studies and Hypothesis}

\subsection{The innovative capability as a resource: Innovation commitment to reach foreign markets.}

According to the Resource-Based View (RBV), the company's capability to generate sustainable and competitive advantages depends on its situation and particular position on resources (Barney, 1991), which allows it to successfully compete with other firms (Penrose, 1959).

Considering an economical context lead by Small and Medium Enterprises (SMEs), it is necessary to underline that those firms suffer because of their structural limitation (Gassmann and Keupp, 2007), and they cannot presume on competitive advantages from their tangible resources. Therefore, crucial resources of these companies are essentially intangibles, such as knowledge. In the SMEs context, the RBV helps to explain how the knowledge and the organizational capabilities are developed and levered up by owner-managers (Knight and Cavusgil, 2004). In this sense, the vision based on knowledge arises from the RBV focused on intangible resources, more than on physical or tangible resources (Gassmann and Keupp, 2007). 
The amount of resources based on knowledge is determinant to generate of organizational capabilities (Teece, et. al., 1997), i.e. organizational capability is the integrated result of different knowledge (Grant, 1996). Consequently, it is highlighted that the innovative capability does not come from the exploitation of external technologies, which competitors have easy access to; hence, they are not enough to maintain a competitive advantage. In contrast, the innovative capability comes from the generation of internal innovation through the generation of new resources and the building of basic technological capabilities (Barney, 1991), as well as the accumulation of intangible resources, specifically based on knowledge (Prashantham, 2005). In addition, technological resources can generate a dual competitive advantage to the company; firstly, the costs diminution through the creation of more efficient and modern productive processes (Schaaper, 2014); and secondly, through the differentiation of innovation in products or services (López Rodriguez and Garcia Rodriguez, 2005; Sánchez-Sellero et. al., 2014).

Trading globally gives companies the opportunity to be exposed to new markets and experiences generating knowledge. In turn, knowledge provides certain advantages that facilitate the entry as well as operations in foreign markets (Johanson and Vahlne, 1991; Knight and Cavusgil, 2004). Namely, knowledge about foreign markets and effectiveness to learn and manage new knowledge will be determinant to the success of entrepreneurial companies (Autio, et. al., 2000). In that way, in innovative companies, owner-managers develop unique knowledge and capabilities that make the process of new resources more dynamic and easy, which promotes a constant market expansion (Eiriz, et. al., 20/3). Likewise, owner-managers take advantage of the technological boost to innovate in the creation and development of new resources, as well as in the adaptation of finished products, which allows and facilitates the entrance to global markets (López-Rodríguez and GarcíaRodríguez, 2005). Moreover, one of the factors that seem to engender or facilitate early internationalization is precisely "the creation of value through the product differentiation. Products with innovative and revolutionary technology" (Rialp, et. al., 2005 p. 160).
Conceptually, an innovative strategic posture is thought to be linked to firm performance (Alpay,et.al.,20I2;Eiriz,et.al.,20I3) because it increases the probability to obtain advantages as the first one which identifies and takes advantages of market opportunities (Wiklund, 1999). Innovative organizations, through the creation and introduction of new products and technologies, develop a market niche with new products or services that are different from them and/or substitute already final versions with better quality, cheaper prices and other values identified by the final consumer (Richard, et. al., 2009; Wiklund and Shepherd, 2005). The innovative capability can be recognized as a key factor for success in a globalized and highly competitive economy (Akman and Yilmaz, 2008; Prasad, 2004). In this sense, there is several evidence, which is evaluating the effect of innovative capability on international activity (i.e. Cassiman and Martínez-Ros, 2007; Kirbach and Schmiedeberg, 2008; Lachenmaier and Wobmann, 2006; Podmetina, et. al., 2009; Roper and Love, 2002).

Ultimately, the last decade has supposed a proliferation in studies which try to identify the relation between innovation and exports. For instance, Caldera (2010) using data from the Encuesta sobre Estrategias Empresariales (ESEE) - Spain, has shown a positive effect of innovation on the internationalization probability through exports. In addition, considering the Spanish manufacturing sector, López-. Rodríguez and García-Rodríguez (2005), pointed out that innovation in products, patents and processes have a positive and significant effect on both the export propensity and international sales. Furthermore, Cassiman and MartínezRos (2007), demonstrated the importance of innovation on the growth of exports, while the innovation in processes is an important factor in export propensity. Recently, Cassiman and Golovko (20II) highlighted that innovation in products improves productive levels, which leads the firm to venture into global markets.

Therefore, in accordance to stated arguments and previous literature, we make the following hypotheses:

Hla. The owner-manager's commitment to innovation increases the likelihood of export propensity.

HIb. The owner-manager's commitment to innovation increases export intensity.

2.2. Learning-by- exporting: From export activities toward innovative commitment 
As indicated before, there is a growing recognition about the relationship between innovativeness and export behavior. Likewise, recent literature on international business has strengthened the analysis on the inverse relation or indeed, the reciprocity between innovativeness and export behavior. Therefore, simultaneously, the effects of export activity on firm's innovativeness might be investigated from the learning-by-exporting perspective. It is known that the ability to identify the capability to catch new knowledge in external environments (Cohen and Levinthal, 1990; Lane and Lubatkin, 1998; Zahra and George, 2002) is a key element to knowledge generation and to the development of innovative capabilities (Salazar, et. al., 20l4). Besides, according to the Knowledge-basedView, innovating is an intensive information and knowledge process. Hence, in order to be creative and make a difference, owner-managers need to access the information and obtain it from several sources, which should as well be from different countries (Kafouros, et. al., 2008).

Despite not being a longitudinal study, this research assumes, in accordance with previous findings (e.g., Eriksson, et. al., 1997; Monreal-Pérez, et. al., 20I2; Sapienza, et. al., 2005), that owner-managers, and consequently organizations, can increase their commitment towards innovation by improving the process of knowledge accumulation and by increasing organizational learning (Kafouros, et. al., 2008). Thus, ownermanagers may learn directly from their experiences in international markets and, indirectly, via observation of foreign companies (Johanson and Vahlne, 1991). External contacts can help owner-managers of companies learn new skills and provide access to certain resources, either tangible or knowledge intensive (Anand and Khanna, 2000; Chetty and Wilson, 2003). That is, organizations can learn from foreign markets and their presence abroad (Sapienza, et. al., 2005).

Therefore, does export propensity increase the ownermanager commitment to innovation? Consistent with the learning-based approach, obviously this is a possible outcome. Although there is no extensive literature that examines the export propensity effect on innovation issues, some authors stress that international trade makes companies more involved with innovation (e.g., Filipescu, et. al., 2009; Molero, 1998; Monreal-Perez, et. al., 2012; Podmetina, et. al., 2009; Salomon and Shaver, 2005). Results could be explained by the need to innovate that some companies have to remain in international markets (Hitt, et. al., 1997). In addition, internationalized companies can increase their networks around the world to access qualified professionals and achieve technical expertise that drives new technologies (Kafouros, et. al., 2008).
Consistently with the learning-by-exporting idea, and in accordance with previous research, the following hypothesis can be addressed:

H2. The export propensity increases the likelihood of owner-manager's commitment to innovation.

\section{Research Methodology}

\section{I. Database}

In this study we use data from the Global Entrepreneurship Monitor (GEM) adult population survey (APS) collected between 2010 and 2011 in Colombia. The GEM research program is an annual assessment of the national levels of entrepreneurial and business activity. Initiated in 1999 it is the single largest study of entrepreneurial activity in the world cumulating nearly 100 national research teams as of 2014. The main advantage of GEM database is the fairly large sample size, in addition to consistency in definition and measures across multiple contexts. Thus, in addition to its external validity the use of GEM dataset allows understanding business and entrepreneurial activity across time and space (see Reynolds, et. al., 2005).

In this study, the units of analysis are individuals who are leading an already established organization (considering only those individuals who own or run a business at the time the survey was done). Thus, the final sample included responses from 1050 individuals in 2010 and 782 individuals in 201 I. The sample characteristics are similar in the two years the analysis was made. From the surveyed individuals, $35 \%(2010)$ and $30 \%(2011)$ were women. By age, in both years approximately $30 \%$ were between 18 and 34 years old, while $70 \%$ were aged between 35 and 64 years. For more information on characteristics of the sample, (see Table I). 


\begin{tabular}{|c|c|c|c|c|c|}
\hline & & \multicolumn{2}{|c|}{2010} & \multicolumn{2}{|c|}{2011} \\
\hline Individuals & & $N$ & $\%$ & $N$ & $\%$ \\
\hline Gender & $\begin{array}{l}\text { Men } \\
\text { Women }\end{array}$ & $\begin{array}{l}680 \\
370\end{array}$ & $\begin{array}{l}64.8 \% \\
35.2 \%\end{array}$ & $\begin{array}{l}540 \\
242\end{array}$ & $\begin{array}{l}69.1 \% \\
30.9 \%\end{array}$ \\
\hline Age & $\begin{array}{l}\text { From } 18 \text { to } 34 \\
\text { From } 35 \text { to } 64\end{array}$ & $\begin{array}{l}337 \\
713\end{array}$ & $\begin{array}{l}32.1 \% \\
67.9 \% \\
\end{array}$ & $\begin{array}{l}263 \\
519\end{array}$ & $\begin{array}{l}33.6 \% \\
66.4 \%\end{array}$ \\
\hline Commitment to innovation & & & & & \\
\hline $\begin{array}{l}\text { Committed with Innovation in } \\
\text { products or services }\end{array}$ & $\begin{array}{l}\text { Yes } \\
\mathrm{No}\end{array}$ & $\begin{array}{l}476 \\
574\end{array}$ & $\begin{array}{l}45.3 \% \\
54.7 \% \\
\end{array}$ & $\begin{array}{l}616 \\
166 \\
\end{array}$ & $\begin{array}{l}78.8 \% \\
21.2 \% \\
\end{array}$ \\
\hline $\begin{array}{l}\text { Committed with Innovation in } \\
\text { process technologies }\end{array}$ & $\begin{array}{l}\text { Yes } \\
\text { No }\end{array}$ & $\begin{array}{l}330 \\
720\end{array}$ & $\begin{array}{l}31.4 \% \\
68.6 \% \\
\end{array}$ & $\begin{array}{l}277 \\
505\end{array}$ & $\begin{array}{l}35.4 \% \\
64.6 \% \\
\end{array}$ \\
\hline $\begin{array}{l}\text { Committed with generating } \\
\text { unique product or service to } \\
\text { market }\end{array}$ & $\begin{array}{l}\text { Yes } \\
\text { No }\end{array}$ & $\begin{array}{l}317 \\
733\end{array}$ & $\begin{array}{l}30.2 \% \\
69.8 \%\end{array}$ & $\begin{array}{l}258 \\
524\end{array}$ & $\begin{array}{l}33 \% \\
67 \%\end{array}$ \\
\hline $\begin{array}{l}\text { Specific characteristics of } \\
\text { the company }\end{array}$ & & & & & \\
\hline Export Propensity & $\begin{array}{l}\text { Export } \\
\text { No export }\end{array}$ & $\begin{array}{l}408 \\
642 \\
\end{array}$ & $\begin{array}{l}38.9 \% \\
61.1 \% \\
\end{array}$ & $\begin{array}{l}465 \\
317 \\
\end{array}$ & $\begin{array}{l}59.5 \% \\
49.5 \% \\
\end{array}$ \\
\hline Export Intensity & $\begin{array}{l}\text { no } \\
\text { Low } \\
\text { medium/high }\end{array}$ & $\begin{array}{l}642 \\
322 \\
86 \\
\end{array}$ & $\begin{array}{l}61.1 \% \\
30.7 \% \\
8.2 \% \\
\end{array}$ & $\begin{array}{l}317 \\
364 \\
101 \\
\end{array}$ & $\begin{array}{l}40.5 \% \\
46.5 \% \\
12.9 \% \\
\end{array}$ \\
\hline Size & $\begin{array}{l}\text { 1-5 employees } \\
6-19 \text { employees } \\
20 \text { o more }\end{array}$ & $\begin{array}{l}863 \\
136 \\
51\end{array}$ & $\begin{array}{l}82.2 \% \\
13 \% \\
4.9 \%\end{array}$ & $\begin{array}{l}597 \\
153 \\
32\end{array}$ & $\begin{array}{l}76.3 \% \\
19.6 \% \\
4.1 \%\end{array}$ \\
\hline $\begin{array}{l}\text { Time of Constitution } \\
\text { Baby/established business }\end{array}$ & $\begin{array}{l}\text { Up to } 42 \text { months } \\
\text { More than } 42 \\
\text { months }\end{array}$ & $\begin{array}{l}469 \\
581\end{array}$ & $\begin{array}{l}44.67 \% \\
55.33 \%\end{array}$ & $\begin{array}{l}418 \\
364\end{array}$ & $\begin{array}{l}53.45 \% \\
46.55 \%\end{array}$ \\
\hline
\end{tabular}

Table I. Characteristics of the Sample. Source: Self-elaborated 


\subsection{Variables}

\section{Export Propensity}

A dichotomous variable was used with the intention of identifying the companies with some experience selling in international markets. Thus, this variable measures whether the company has a behavior focused on exports or not. If I\% or more of the sales were abroad, this variable assumed the value of I. On the other hand, if the company had no foreign sales, this variable assumed the value of 0 .A similar measure was used to define export propensity, which has been managed by Gonzalez- Pernia and Peña- Legazkue (20II).

\section{Export Intensity}

It is the dependent variable in the first part of our analysis. This variable corresponds to the rate of sales abroad divided by the total sales within a specific period (Pan and Chi, 1999). In fact, according to Katsikeas, et. al., (2000), this is the main criteria to measure export performance. Therefore, a categorical variable was created, which takes the value of I if the company does not export, a value of 2 if its exporting rates are between $1 \%$ and $25 \%$ (low), and a value of 3 if the export rate exceeds the $26 \%$ (medium/ high) . Our ranking is based on Acs and Amorós (2008), who captured the "export business orientation" considering the importance of a "relatively high rate of foreign market". The purpose is to generate an ordinal ranking that seeks to identify nonexporting firms and those with a significant and growing ratio of their revenue from overseas sales.

\section{Commitment to Innovation}

The construct "commitment to innovation" is part of the information available in the GEM survey and its dimensions show the position of the organization's owner-manager in the challenge of developing internal creative and novel solutions, or external offers with these same characteristics (see Reynolds, et. al., 2005). Questions related to commitment to innovation indicate the effort levels by the owner-managers to show to potential customers their novel products and services, and the technologies and processes are new or are being updated constantly. Therefore, values concerning commitment to innovation are: about the innovation in products or services, this assumes the value one (I) in the cases that the owner- manager affirms an innovative behavior and zero value ( 0 ) for a non-innovative behavior. Similarly, for the process technology managed in generating the product or service offered by the company, it assumes the value of one (I) when the owner- manager mentions that the company uses technologies under five years of creation (new) and zero value $(0)$ to technologies created over five years ago (obsolete). Finally, considering the uniqueness of products or services, the variable takes the value of one (I) when the owner-manager says there are not or very few businesses that offer the same product or service to potential customers, and a value of zero ( 0 ) if there are many other businesses offering the same product or service to potential customers.

\section{Control Variables:}

\section{Gender}

In the Colombian case, it is shown that there are significant differences between men and women regarding entrepreneurial activity. According to GEM - Colombia (2012), there is a high gender disparity in Colombia, in comparison with the reported average by LAC countries, regarding the rate of entrepreneurial activity (TEA). According to the aforementioned information, to control possible differences from the owner-manager gender, a dichotomous variable has been introduced, which assumes the value of one $(I)$ when the owner-manager is a man and a value of zero ( 0 when the owner-manager is a woman.

\section{Age}

Like in the gender case, age may influence the results when the individual is the object of analysis (Fuentes and Sánchez, 2010). The Colombian case shows, that in some age groups, there is a greater proportion of entrepreneurs, as well as differences in age characteristics among established entrepreneurs (GEM-Colombia, 20I2). Thus, a binary control variable for age is introduced, considering two age groups: the variable assumes the value of one (I) when the owner- manager is between 18 and 34 years old, and a value of zero (0) when the owner-manager is between 35 and 64 years old.According to GEM classification, the range from 18 to 34 years of age owns the highest proportion of entrepreneurs by opportunity. It is expected that between entrepreneurs by opportunity; also, it could imply an identification of a higher rate of owner-managers committed to innovation aspects.

\section{Firm Size}

In the model that explains the firm export behavior, it is included a variable that captures the size as a domestic resource considering that specific factors of the company can provide some competitive advantages in exporting. Therefore, it is expected that the size of a company has a positive relation towards exports given that larger companies have more resources to venture into international markets (Fariñas and Martin-Marcos, 2007). To define the firm size, the number of employees was considered (Andersson, et. al., 2004; Cassiman and Golovko, 20II). The size variable 
follows the classification available in the GEM survey and assumes the value one (I) when the company has between I and 5 employees, the value of two (2) when the company has between 6 and 19 employees, and eventually it assumes the value of three (3) when the company has 20 or more employees.

\section{Time of Constitution}

The age of the company is an additional feature that may differ between exporters and non-exporters (Caldera, 2010; Monreal-Perez, et. al., 2012). Exporters are usually older than non-exporters (Fariñas and Martin-Marcos, 2007). Age has been introduced in the model considering the time of constitution of the firm as it is classified by GEM. Thus, the binary variable takes the value one (I) when the company has operated for more than 42 months (established), and assumes zero value ( 0 ) when the time of constitution of the organization is less than $\mathbf{4 2}$ months (baby business).

\subsection{Techniques for controlling common method biases}

In studies that manage information about individual or corporate behavior, it is important to contemplate the different methods of biases that may influence the response process. Especially when the dependent variable and independent variables are measured with the same instrument (survey), the possibility of the existence of correlation between them increases, skewing the estimators (Podsakoff, et. al., 2003). One of the most used techniques is the Harman one-factor test (Meade, et. al., 2007; Rhee, et. al., 2010). The basic hypothesis of this test is that if there is a significant amount of common method variance, a single factor will emerge from the factor analysis or most of the covariance will be concentrated on one factor (Podsakoff, et. al., 2003, p.889). However, as it is expected from a components factor analysis with measuring variables, different factors were obtained with values greater than 1.0 which explained more than $70 \%$ of the total variance obtained. Therefore, a single factor has not emerged, and neither has it been seen that a single factor has accumulated all of the variances. These results show the validity of the variables measurement used in the study, and indicate that it is doubtful that a common method bias will be a problem in the data.

\section{Analysis and Findings}

Before the regression analysis, possible correlations were observed between the variables of the model. It was evidenced that for the magnitude of the correlation between independent variables, in both logistic regression and ordinal regression, multicollinearity is not a problem (Hair, et. al.,
1998). Indeed, a correlation was expected between the commitment to innovation in products and services, and in process technology, but this value was not significant.

\section{I. Contrasting hypothesis I: \\ The owner-manager's commitment to innovation and the company export behavior.}

In order to test Hypotheses Ia and I $\mathrm{b}$, an Ordinal Regression Model or Polytomous Universal Model (PLUM) was applied. Given that the multinomial regression model ignores any ordering among values that can take the dependent variable, and our dependent variable presents a clear ordering of the values, we apply a model that incorporates the ordinal nature of the dependent variable.

In the Polytomous Universal Model, the interest situation is to observe a particular value. For instance:

$$
\begin{aligned}
& \text { Rating } \mathrm{I}=(\operatorname{Prob}(\text { value of } \mathrm{I})) /(\operatorname{Prob}(\text { value }>I)) \\
& \text { Rating } 2=(\text { Prob }(\text { value of } \mathrm{I} \text { or } 2)) /(\text { Prob }(\text { value }>2))
\end{aligned}
$$

The last category does not have an associated probability given that the chance to obtain a high value that includes the last date is I. Consequently, the equation to explain it is:

$\varnothing_{\mathrm{j}}=(\operatorname{Prob}($ value $\leq \mathrm{j})) /(\operatorname{Prob}($ value $>\mathrm{j}))$

The Table 2 explains the estimated coefficients of the model. Estimates called ratings are the threshold (terms of equivalent intersection), and it is possible to observe an estimated growing coefficient with an increasing scale.

Regarding the control variables included in the model, a positive effect of a firm size is observed, including its time of constitution. In 2010, coefficients confirmed that there is a high possibility in the propensity and export intensity in organizations with more than $\mathbf{4 2}$ months of life (established) compared to organizations with less time since its creation (baby business). This relation was less significant in the year of 201I; however, it was identified as well. On the other hand, the tendency of a positive impact of firm size on the propensity and export intensity of analyzed organizations was also confirmed. In both years, it was observed that the group of organizations with between 6 and 19 employees and organizations with 20 or more employees increase the likelihood of exporting, as well as having better levels of exports than firms with up to 5 employees.

Concerning the influence of an owner-manager's innovative capability on the export behavior, the study findings allow us to confirm the existence of a positive and significant effect on both the propensity and the export intensity of 
the organizations in the sample. Considering the ownermanager's commitment with the products and services innovation, our findings confirm that firms where ownermanagers make an effort in convincing clients about the innovation of their products and services, increases the likelihood of export propensity and even the intensity of these exports. Taking into account the results of 2010 and $201 \mathrm{I}$, the coefficients are very similar in both years and confirm a positive and significant relationship between the commitment of owner-managers with innovativeness and export behavior. For instance, (2010: i.ProdServ $=.845$ $\mathrm{p}<.00 \mathrm{I}$; i.TechProc $=.207 \mathrm{p}<.10$ y $20 \mathrm{II}$ : i.ProdServ $=.468$ $\mathrm{p}<.005$; i.TechProc $=.314 \mathrm{p}<.005)$. When analyzing the commitment with the generation and supply of unique products on the market, the results confirm a positive effect only in 201 I. Following this, the results are not significant enough to say that organizations without competitors offering similar product or service increase the probability of export propensity and intensity.
Given the analysis with the PLUM model, the overall results confirm a positive relationship between innovation capacity and propensity to export, as well as an increase in export intensity. Therefore, the $\mathrm{HIa}$ and $\mathrm{HIb}$ hypotheses are confirmed.

\subsection{Export propensity and the owner-manager's commitment to innovation}

In order to explore whether export propensity can explain the innovative capability perceived from owner-managers, a procedure was developed which allows to estimate the probability of an expected event. Given that the dependent variable is binary, the model of logistic regression was the most appropriate. The logistic regression is an analysis that directly predicts the occurrence probability of an event (Hair, et. al., 1998); therefore, it permits to identify whether export propensity is relevant to categorize owner-managers as innovators and committers with innovation aspects or not. Table 3 (next) shows the results of the logistic regression.

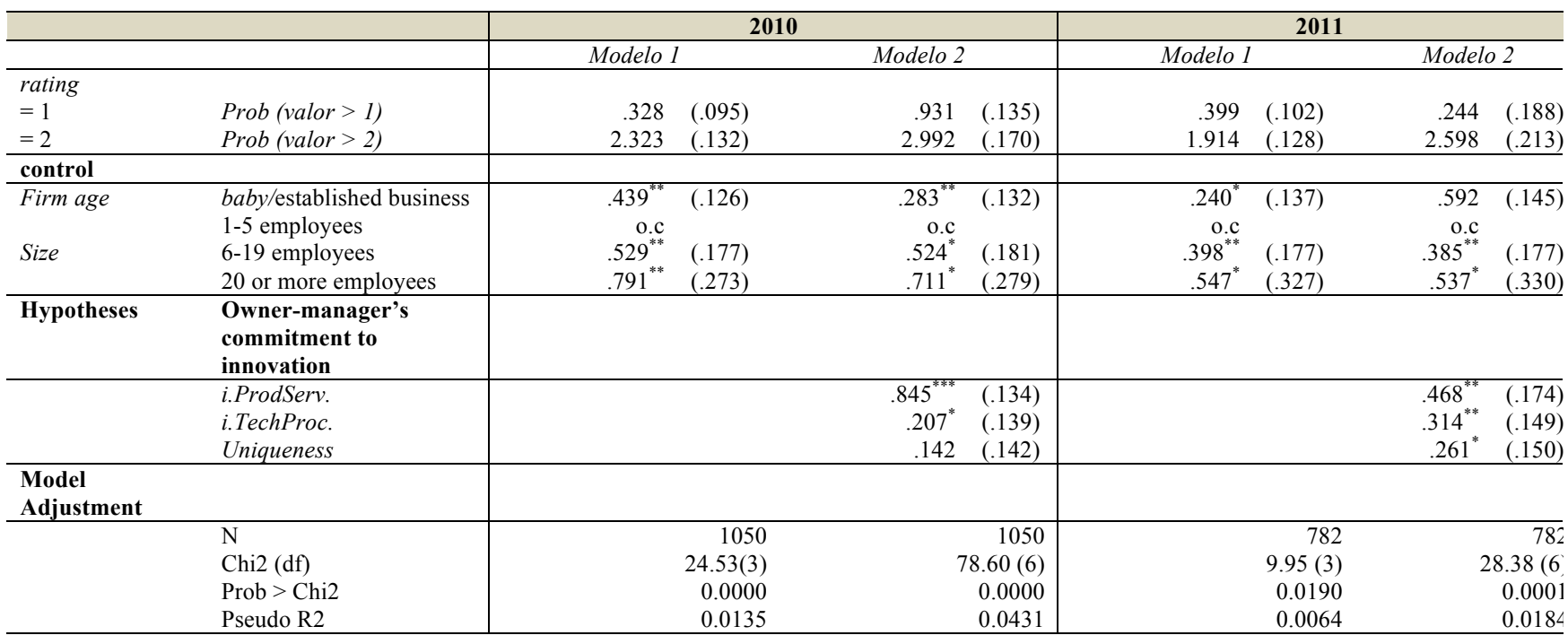

Table 2. Ordinal Regression: Export behavior

Note: ${ }^{*} \mathrm{p}<0.10$; ${ }^{* *} \mathrm{p}<0.05$; ${ }^{* *} \mathrm{p}<0.01$. The numbers in brackets are standard errors. o.c omitted category and the parameter is zero because it is redundant.

ISSN: 07I 8-2724. (http://www.jotmi.org) 
The statistical test of Chi-square distribution, with the complete models of i.ProdServ and i.TechProc, indicates that there is a positive relation between the group of independent and dependent variables. The Table 3 shows the degree of probability, the significance in the appropriate level and the standard deviation. The predicted values of dependent variables are related to the coefficient that predicts the increase or decrease of the probability that an event happens, and the interpretation is analogous to the lineal regression (Hair, et. al., 1998). A positive coefficient implies that an increase in these variables represents a high probability that the owner-manager is committed with innovation.

Regarding the control variables, the outcomes suggest interesting revelations in relation with the gender of ownermanagers, as well as with different age groups. Gender seems to be relevant in determining the owner-manager's commitment with innovativeness. From the coefficients of the regression model, a decrease is observed in ownermanagers' probability to recognize their involvement with innovation when the dependent variable takes the value of one (I), i.e. when the owner-manager is a man. In $201 \mathrm{I}$, these results were more robust since they are statistically significant in both models (model just with control variables and full model). Furthermore, in $201 \mathrm{I}$ these results were confirmed in the two dependent variables.
In turn, considering age as a control variable, we can observe that owner-managers between 18 and 34 years of age, have a higher probability to be committed with innovativeness compared to owner-managers aged 35 and 64 years old. In both 2010 and 20II, a positive and significant effect of the age group between 18 and 34 years old was confirmed on the innovation capability in products and services, as well as in the latest process technology usage, which has been confirmed.

Regarding Hypothesis 2, we examined whether the change in the binary variable (export propensity "yes/ no") increased the likelihood that owner-managers were committed to innovation. Results in Table 3 show that the propensity to export has a positive and significant effect on the innovativeness of the owner-managers surveyed. Thus, the probability that the event occurs is higher in exporters than in no-exporters. In addition, outcomes confirm that the propensity to export has a high explanatory power in both 2010 and 201 I. For instance, (findings 2010: i.ProdServ .996 $p<.01$; iTechProc . $370 p<.05$; findings 20I I: i.ProdServ 606 $\mathrm{p}<.0 \mathrm{I}$; iTechProc $.538 \mathrm{p}<.0 \mathrm{I}$ ). Therefore, hypothesis 2 is confirmed as well.

\begin{tabular}{|c|c|c|c|c|c|c|c|c|c|}
\hline & & \multicolumn{4}{|c|}{2010} & \multicolumn{4}{|c|}{2011} \\
\hline \multicolumn{2}{|l|}{ control } & \multicolumn{2}{|c|}{ i.ProdServ } & \multicolumn{2}{|c|}{ i.TechProc } & \multicolumn{2}{|c|}{ i.ProdServ } & \multicolumn{2}{|c|}{ i.TechProc } \\
\hline & & Model 1 & Model 2 & Model 1 & Model 2 & Model 1 & Model 2 & Model 1 & Model 2 \\
\hline gender & & $\begin{array}{l}-.206 \\
(.130)\end{array}$ & $\begin{array}{l}-.226^{*} \\
(.134)\end{array}$ & $\begin{array}{l}-.186 \\
(.139)\end{array}$ & $\begin{array}{l}-.190 \\
(.139)\end{array}$ & $\begin{array}{l}-.602^{* *} \\
(.206)\end{array}$ & $\begin{array}{l}-.632^{* *} \\
(.208)\end{array}$ & $\begin{array}{l}-.309^{*} \\
(.161)\end{array}$ & $\begin{array}{l}-.337^{* *} \\
(.163)\end{array}$ \\
\hline age & Binary & $.426^{* *}$ & $.347^{* *}$ & $.632^{* * * *}$ & $.598^{* * *}$ & $.589^{* *}$ & $.538^{* *}$ & $490^{* *}$ & $.453^{* *}$ \\
\hline & & $(.133)$ & $(.137)$ & $(.139)$ & $(.140)$ & $(.200)$ & $(.201)$ & $(.157)$ & $(.158)$ \\
\hline \multicolumn{10}{|c|}{ Hypothesis } \\
\hline & $\begin{array}{l}\text { Export } \\
\text { Propensity }\end{array}$ & & $\begin{array}{l}.996^{* * * *} \\
(.131)\end{array}$ & & $\begin{array}{l}.370^{* *} \\
(.136)\end{array}$ & & $\begin{array}{l}.606^{* * *} \\
(.178)\end{array}$ & & $\begin{array}{l}.538^{* * * *} \\
(.158)\end{array}$ \\
\hline \multicolumn{10}{|c|}{$\begin{array}{l}\text { Model } \\
\text { Adjustment }\end{array}$} \\
\hline & $\mathrm{N}$ & 1050 & 1050 & 1050 & 1050 & 782 & 782 & 782 & 782 \\
\hline & LR Chi2 (df) & $12.83(2)$ & $71.88(3)$ & $22.22(2)$ & $29.50(3)$ & $16.92(2)$ & $28.41(3)$ & $12.43(2)$ & $24.22(3)$ \\
\hline & Prob $>$ Chi2 & 0.0016 & 0.0000 & 0.0000 & 0.0000 & 0.0002 & 0.0000 & 0.0020 & 0.0000 \\
\hline & Pseudo R2 & 0.0089 & 0.0497 & 0.0170 & 0.0226 & 0.0209 & 0.0351 & 0.0122 & 0.0238 \\
\hline
\end{tabular}

Table 3. Logistic Regression: Owner-manager's commitment to innovation Note: ${ }^{*} \mathrm{p}<0.10 ; * * \mathrm{p}<0.05 ; * * * \mathrm{p}<0.01$. The numbers in brackets are standard errors.

ISSN: 07I 8-2724. (http://www.jotmi.org) 


\section{Discussion and Conclusions}

The purpose of this paper has been to explore the role of owner-manager's commitment to innovation on firm export behavior, as well as a reverse effect of export propensity on the innovation capability of owner-managers.

There was a particular emphasis on products or services innovation; the latest process technologies usage; the creation or offer of unique products and services on the market; and the percentage of foreign sales. Overall, our findings indicate the existence of simultaneous effects between perceived ability of innovation in owner-managers and the export behavior of organizations in 2010 and 2011 in Colombia.

Colombia, as well as the remaining countries from the LAC, is a region that has a considerable entrepreneurial activity but with a little innovative boost. On one hand, the company growth and survival will be directly joined with the commitment with innovation and the access to new markets. On the other hand, only a third part of surveyed ownermanagers, in both years, have confirmed their commitment with the latest processes and technology usage and with the generation of unique services and products to the market. This kind of evidence helps understand the high rate of business mortality which fails to exceed three years from their constitution.

Considering the owner-manager commitment with innovation and firm's export behavior, our findings indicate a positive influence of the group of proposed variables on the propensity, as well as on the export intensity. This implies that the owner-manager's commitment to innovation can change the behavior of the organization. So when the ownermanager is committed with innovation, the probability that firms enter to export markets increases, as well as the probability of obtaining higher levels of foreign sales. In this sense, our empirical findings support recent studies which provide new evidence about theories on innovation and international business (e.g., Cassiman and Golovko, 201 I; Filipescu, et. al., 2009; Kirbach and Schmiedeberg, 2008).

In turn, the learning-by-exporting hypothesis predicts that owner-manager's commitment to innovation will increase if the company has export activities. Our findings corroborate this argument. The positive association between export propensity and owner-manager's commitment observed in the second part of the analysis confirms that firms do increase the perceived innovation in products or services, as well as the innovation related to usage of technology if they are export-oriented. This innovative superior capability can be related to the organization's ability to obtain new knowledge in a market where there is export activity. In this way, exporting firms tend to increase their innovative capability absorbing the knowledge and ideas from other countries. Therefore, our findings are consistent and support the results that indicate the knowledge existence through the export experience, highlighted in the literature (Kafouros, et. al., 2008; Monreal-Pérez, et. al., 2012; Salomon and Jin, 2008; Salomon and Shaver 2005).

Additionally, considering two consecutive years, our results can indicate a tendency on proposed relations in the study. Therefore, it can be said that our study contributes to academic literature and presents some practical implications. For academics, this study is adhered to the research area that explains the background of the export decision. The study provides a different perspective which shows evidence from the owner-managers and their commitment to innovative capability within organizations.

In summary, the owner-manager's ability to assume the role of responsible for decisions that lead to innovation in products or services, is central to addressing global challenges. Besides, the use of the latest process technologies must also be interpreted as a facilitator to entry into export markets. This research contributes to different studies on underexploited dimensions (e.g., the effect of export propensity on the innovative capability of an enterprise). Therefore, the theoretical contributions of this study lie on the research extension on innovative capability with an emphasis on the export propensity.

For owner-managers of organizations, especially in the Latin American context, it is important to know that firms which practice the culture of innovation will have greater ability to access international markets and increase their sales beyond their borders. Equally as important to responsible of strategic decisions, outcomes of this study suggest that exporting is more than a decision to increase sales and achieve other markets. While they learn by their experience from other foreign markets, firms, through their owner-managers, must increase their capability to innovate.

This paper is subjected to some limitations that classify the behavioral research and suggest caution when interpreting its results. We could observe that there are mutual effects between the innovative capability and export behavior; however, a potential limitation would be that the design of transversal analysis of this research does not guarantee the direction of causality between the variables. On the other hand, central hypotheses are based on solid literature and it makes researchers presume a bidirectional relation. Future research could be validated through the use of panel data to predict if the innovative capability increases the probability to accede foreign markets (e.g., Cassiman and Golovko, 20I I; Filipescu, et. al., 20I3; Monreal-Pérez, et. al., 20I2). Moreover,

ISSN: 07I 8-2724. (http://www.jotmi.org)

Journal of Technology Management \& Innovation @ Universidad Alberto Hurtado, Facultad de Economía y Negocios. 
future studies can include a longitudinal perspective that observes the effects of learning-by-exporting on the innovative capability of organizations (e.g., Damijan, et. al., 2010; Salomon and Shaver, 2005). It would enable us to clarify these relationships.

\section{About Authors:}

Izaias Martins: Ph.D. en Entrepreneurship and Business Management por la Universidad Autónoma de Barcelona Barcelona/España (título recibido en 20I3).

Magister en Creación, Estrategia y Gestión de Empresas por la Universidad Autónoma de Barcelona - España (título recibido en 2010).

Diploma de estudios avanzados en Economía, Finanzas y Contabilidad (Msc), por la Universidad Autónoma de Barcelona - Barcelona/España (título recibido en 20l I).

Licenciado en Administración y Dirección de Empresas por la Universidad Federal de Pelotas - Pelotas/Brasil, (título recibido en 2005).

Actualmente es profesor de tiempo completo en la Escuela de Administración de la Universidad EAFIT en Medellín Colombia.

Eduardo Gómez-Araujo: Ph.D(c) en Creación, Estrategia y Gestión de Empresas, Universidad Autónoma de Barcelona Barcelona/España (título a ser recibido en 2014).

Magister en Creación, Estrategia y Gestión de Empresas (Msc), Universidad Autónoma de Barcelona - Barcelona/ España (título recibido en 20I l).

Diploma de estudios avanzados en Creación, Estrategia y Gestión de Empresas (Msc), Universidad Autónoma de Barcelona - Barcelona/España (título recibido en 20I I).

Historiador, Universidad del Atlántico - Barranquilla/ Colombia (título recibido en 2004).

Actualmente es profesor de tiempo completo en la Escuela de Negocios de la Universidad del Norte en Barranquilla Colombia

Yancy Vaillant: Ph.D. en Entrepreneurship and Business Management por la Universidad Autónoma de Barcelona Barcelona/España (título recibido en 2006).

Master (MA) de l'Université de Sherbrooke - Sherbrooke/ Canada (título recibido en 1999).

Diplomas de posgrados:

Vaxjo University (Vaxjo, Sweden), 2000

ICRPS research consortium (Canada/EE.UU./UE), 2005

Massachusetts Institute of Technology MIT Sloan School of Management (Cambridge, USA), 2008.

BA de la Concòrdia University (Montreal, Canada), 1994.

Actualmente es profesor de tiempo completo en el Departamento de Economía de la Empresa de la Universidad Autónoma de Barcelona - España, y profesor asociado en el ESC Rennes School of Business - Francia.

\section{References}

ACS, Z. J., Amorós J. E. (2008). Entrepreneurship and competitiveness dynamics in Latin America. Small Business Economics, 3I(3), 305-322. doi:http://dx.doi.org//0.1007/ sl II87-008-9133-y

AKMAN, G., Yilmaz, C. (2008). Innovative capability, innovation strategy and market orientation: an empirical analysis in Turkish software industry. International Journal of Innovation Management, I2(0I), 69-I I I. doi:http://dx.doi. org/I0.II42/s I 3639I960800I923

ALPAY, G., Bodur, M., Yilmaz, C., Buyukbalci, P. (20I2). How does innovativeness yield superior firm performance? The role of marketing effectiveness. Innovation: Management, Policy \& Practice, I4(I), 107-128. doi:http://dx.doi. org/I0.5I72/impp.20I2.14.I.107

AMORÓS, J.E., Cristi, O. (2008). Longitudinal analysis of entrepreneurship and competitiveness dynamics in Latin America. International Entrepreneurship and Management Journal, 4(4), 38I-399. doi:http://dx.doi.org//0.1007/s I I365008-0082-3

ANAND, B.N., Khanna, T. (2000). Do firm learn to create value? The case of alliances. Strategic Management Journal, 2I(3), 295-3I5. doi:http://dx.doi.org//0.1002/(sici)I0970266(200003)21:3<295::aid-smj9|>3.3.co;2-f

ANDERSSON, S., Gabrielsson, J., Wictor, I. (2004). International activities in small firms: examining factors influencing the internationalization and export growth of small firms. Canadian Journal of Administrative Sciences, 2I (I),22-34.doi:http://dx.doi.org/I0.1 I I I/j.1936-4490.2004. tb00320.x

AUTIO, E., Sapienza, H.J., Almeida, J.G. (2000). Effects of age at entry, knowledge intensity, and imitability on international growth. Academy of Management Journal, 43(5), 909-24. doi:http://dx.doi.org//0.2307//5564/9

BARNEY,J.(|99|). Firm resources and sustained competitive advantage. Journal of Management, I7(I), 99-120. doi:http:// dx.doi.org/I0.1I77/014920639101700108

CALDERA, A. (2010). Innovation and exporting: evidence from Spanish manufacturing firms. Review of World Economics, 146(4), 657-689. doi:http://dx.doi.org//0.1007/ s10290-010-0065-7 
CASSIMAN, B., Golovko, E. (20II). Innovation and internationalization through exports. Journal of International Business Studies, 42(I) 56-75. doi:http://dx.doi.org// 0.1057/ jibs.2010.36

CASSIMAN, B., Martínez-Ros, E. (2007). Product innovation and exports. Evidence from Spanish manufacturing, IESE Business School, Barcelona, I-36.

CHETTY, S.K., Wilson, H. (2003). Collaborating with competitors to acquire resources. International Business Review, I2(I), 6I-8I. doi:http://dx.doi.org//0.1016/s0969593 I (02)00088-4

COHEN,W.M., Levinthal, D.A. (1990). Absorptive capacity: a new perspective on learning and innovation. Administrative Science Quarterly, 35(I) 128-152. doi:http://dx.doi. org// 0.2307/2393553

DAMIJAN,J.P., Kostevc, C.,Polanec,S. (2010). From innovation to exporting or vice versa? The World Economy, 33(3), 374398. doi:http://dx.doi.org//0.1 I I I/j.I467-970I.2010.01260.x

EIRIZ, V., Faria, A., Barbosa, N. (20I3). Firm growth and innovation: toward a typology of innovation strategy. Innovation: Management, Policy \& Practice 15(I), 97-III. doi:http://dx.doi.org// 0.5 I72/impp.2013.15.1.97

ERIKSSON, K., Johanson, J., Majkgard, A., Sharma, D. (1997). Experimental knowledge and cost in the internationalization process. Journal of International Business Studies, 28(2), 337360. doi:http://dx.doi.org//0.1057/palgrave.jibs.8490 I 04

FARIÑAS, J.C., Martín-Marcos, A. (2007). Exporting and economic performance: firm-level evidence of Spanish manufacturing. The World Economy, 30(4), 6I8-646. doi:http://dx.doi.org//0.1 I I I/j.1467-970I.2007.01007.x

FILIPESCU, D.A., Prashantham, S., Rialp, A., Rialp, J. (20/3). Technological Innovation and Exports: Unpacking Their Reciprocal Causality. Journal of International Marketing, 2I (I), 23-38. doi:http://dx.doi.org/I 0.1509/jim. I2.0099

FILIPESCU, D.A., Rialp,A., Rialp, J. (2009). Internationalisation and technological innovation: empirical evidence on their mutual relationship. Advances in International Marketing, 20, I25-I54. doi: http://dx.doi.org//0.1/08/s/4747979(2009)0000020008

FUENTES, F.J., Sánchez, S.M. (2010). Análisis del perfil emprendedor: una perspectiva de género. Estudios de Economía Aplicada, 28(3), I-28.
GASSMANN, O., Keupp, M.M. (2007). The competitive advantage of early and rapidly internationalising SMEs in the biotechnology industry: a knowledge-based view. Journal of World Business, 42(3), 350-366. doi:http://dx.doi. org/I0.1016/j.jwb.2007.04.006

GLOBAL Entrepreneurship Monitor. (2012). Reporte GEM Colombia 200I-20I2.

GOLOVKO, E., Valentine, G. (20II). Exploring the complementarity between innovation and export for SMEs' growth. Journal of International Business Studies, 42(3), 362380. doi:http://dx.doi.org/10.1057/jibs.20I I.2

GONZÁLEZ-PERNÍA, J., Peña-Legazkue, I. (20II). FDI, external knowledge and the export-oriented behaviour of Spanish early-stage entrepreneurs. In 5th Global Entrepreneurship Research Conference, 6-8 October, Cartagena de Indias (Colombia).

GRANT, R.M. (1996). Prospering in dynamically-competitive environments: organizational capability as knowledge integration. Organization Science, 7(4), 375-387. doi:http:// dx.doi.org// 0.1287/orsc.7.4.375

HAIR, J.F., Anderson, R.E., Tatham, R.L., Black, W.C. (1998). Multivariate data analysis. (5thed). Prentice-Hall International Corp: London.

HITT, M.A., Hoskisson, R.E., Kim, H. (1997). International diversification: effects on innovation and firm performance in product diversified firms. Academy of Management Journal, 40(4), 767-798. doi:http://dx.doi.org//0.2307/256948

HULT, G.T.M., Hurley, R.F., Knight, G.A. (2004). Innovativeness: Its antecedents and impact on business performance. Industrial Marketing Management, 33(5), 429-438. doi:http:// dx.doi.org/I0.1016/s0019-850I(03)00II6-0

JOHANSON, J., Vahlne, J.E. (1990). The mechanism of internationalisation. International Marketing Review, 7(4), I |-24. doi:http://dx.doi.org/|0.| | 08/0265 |3390|0|374|4

KAFOUROS, M.I., Buckley, P.J., Sharp, J.A. and Wang, C. (2008). The role of internationalization in explaining innovation performance. Technovation, 28(I), 63-74. doi:http://dx.doi. org//0.1016/j.technovation.2007.07.009

KATSIKEAS, C.S., Leonidou, L.C., Morgan, N.A. (2000). Firm-level export performance assessment: review, evaluation, and development. Journal of the Academy of Marketing Science, 28(4), 493-5II. doi:http://dx.doi. org/ I0.1 I 77/0092070300284003 
KIRBACH, M., Schmiedeberg, C. (2008). Innovation and export performance: adjustment and remaining differences in East and West German manufacturing. Econ. Innov.New Techn, 17(5), 435-457. doi:http://dx.doi. org//0.1080/I043859070/357/89

KNIGHT, G.A., Cavusgil, S.T. (2004). Innovation, organizational capabilities, and the born-global firm. Journal of International Business Studies, 35(2), |24- I4I. doi:http:// dx.doi.org//0.1057/palgrave.jibs.840007|

LACHENMAIER, S., Wobmann, L. (2006). Does innovation cause exports? Evidence from exogenous innovation impulses and obstacles using German micro data. Oxford Economic Paper, 58(2), 3|7-350. doi:http://dx.doi. org// 0.1093/oep/gpi043

LANE, P.J., Lubatkin, M. (1998). Relative absorptive capacity and interorganizational learning. Strategic Management Journal, 19(5), 46I-477. doi:http://dx.doi.org//0.1002/ (sici) |097-0266(| |99805) | 9:5<46|::aid-smj953>3.3.co;2-c

LEDERMAN, D., Messina, J., Pienknagura, S., Rigolini, J. (2014). El emprendimiento en América Latina: muchas empresas y poca innovación (Resumen). Banco MundialWashington, DC. López-Rodríguez J y García-Rodríguez R (2005) Technology and export behaviour: a resource-based view approach. International Business Review, 14(5), 539-557. doi:http:// dx.doi.org//0.1016/j.ibusrev.2005.07.002

MEADE, A.W.,Watson, A.M., Kroustalis, M. (2007). Assessing common methods bias in organizational research. In 22nd Annual Meeting of the Society for Industrial and Organizational Psychology Proceedings, New York, (pp. I-6). doi:http://dx.doi.org//0.1037/e5/8532013-132

MOLERO, J. (1998). Patterns of internationalization of Spanish innovatory firms. Research Policy, 27(5), 541-558. doi:http://dx.doi.org//0.1016/s0048-7333(98)00064-x

MONREAL-PÉREZ, J., Aragón-Sánchez, A., Sánchez-Marín, G. (2012). A longitudinal study of the relationship between export activity and innovation in the Spanish firms: the moderating role of productivity. International Business Review, 2I(5), 862-877. doi:http://dx.doi.org/10.1016/j. ibusrev.2011.09.010

PAN,Y., Chi, P.S.K. (1999). Financial performance and survival of multinational corporations in China.Strategic Management Journal, 20(4), 359-374. doi:http://dx.doi.org//0.1002/ (sici) I097-0266( I 99904)20:4<359::aid-smj3 I>3.0.co;2-9
PENROSE, E. (1995). The Theory of the growth of the firm. Basil Blackwell, Oxford. doi:http://dx.doi.org//0.1093/01982 89774.001 .0001

PODMETINA, D., Smirnova, M., Vaatanen, J., Torkkeli, M. (2009). Innovativeness and international operations: cause of Russian R\&D companies. International Journal of Innovation Management, I 3(02), 295-3 I7. doi:http://dx.doi.org/I0.I I42/ s1363919609002303

PODSAKOFF, P.M., MacKenzie, S.B. Lee, J., Podsakoff, N. (2003). Common method biases in behavioral research: a critical review of the literature and recommended remedies. Journal of Applied Psychology, 88(5), 879-903. doi:http:// dx.doi.org/10.1037/002I-9010.88.5.879

PRASAD, R. (2004). Transformation of national innovations systems towards the knowledge economy in a globalised world, with special reference to key industrial sector in India. Innovation: Management, Policy \& Practice, 6(3), 392-403. doi:http://dx.doi.org/10.5 I72/impp.2004.6.3.392

PRASHANTHAM, S. (2005). Toward a knowledge-based conceptualization of internationalization. Journal of International Entrepreneurship, 3(I), 37-52. doi:http://dx.doi. org/ $/ 0.1007 / \mathrm{s} 10843-005-0304-5$

REYNOLDS, P., Bosma, N., Autio, E., Hunt, S., De Bono, N., Servais, I., Lopez-Garcia, P., Chin, N. (2005). Global entrepreneurship monitor: data collection design and implementation 1998-2003. Small Business Economics, 24(3), 205-23 I. doi:http://dx.doi.org/|0.1007/s I I |87-005-1980- I

RHEE, J., Park, T., Lee, D.H. (2010). Drivers of innovativeness and performance for innovative SMEs in South Korea: mediation of learning orientation. Technovation, 30(I), 6575. doi:http://dx.doi.org// 0.1016/j.technovation.2009.04.008

RIALP, A., Rialp, J., Knight, G.A. (2005). The phenomenon of early internationalizing firms: what do you know after a decade (1993-2003) of scientific inquiry? International Business Review, 14(2), 147-166. doi:http://dx.doi. org/I0.1016/j.busrev.2004.04.006

RICHARD, O.C., Wu, P., Chadwick, K. (2009). The impact of entrepreneurial orientation on firm performance: the role of CEO position tenure and industry tenure. The international Journal of Human Resource Management, 20(5), I078-1095. doi:http://dx.doi.org//0.1080/09585 | 9090285028 |

ROPER, S., Love, J.H. (2002). Innovation and export performance: evidence from the UK and German manufacturing plants. Research Policy, 3I(7), 1087-II02. doi:http://dx.doi.org/I0.1016/s0048-7333(0I)00175-5 
SALAZAR, F., Cavazos, J., Poch, J., Santos, F. (20I4). Cognición de la Innovación Industrial en América Latina: Avances y Desafíos. Journal of technology management \& innovation, $9(I), \quad$ |48-I57. doi:http://dx.doi.org//0.4067/s07/827242014000100012

SALOMON, R.,Jin, B. (2008). Does knowledge spill to leaders or laggards? Exploring industry heterogeneity in learning by exporting. Journal of International Business Studies, 39(I), | 32-I50. doi:http://dx.doi.org//0.1057/palgrave.jibs.8400320

SALOMON, R., Shaver, J. (2005). Learning-by-exporting: new insights from examining firm innovation. Journal of Economics and Management Strategy, I4(2), 43I-460. doi:http://dx.doi. org/I0.1 I I I/j. I530-9|34.2005.00047.x

SAPIENZA, H.J., De Clercq, D., Sandberg, W.R. (2005). Antecedents of international and domestic learning effort. Journal of Business Venturing, 20(4), 437-457. doi:http:// dx.doi.org/I0.1016/j.jbusvent.2004.03.00 I

SÁNCHEZ-SELLERO, P., Sánchez-Sellero, M., SánchezSellero, F. J. and Cruz-González, M. M. (20I4). Innovación y productividad manufacturera. Journal of technology management \& innovation, 9(3), 135-145. doi:http://dx.doi. org/I0.4067/s07/ 8-272420I40003000I0

SCHAAPER, M. (20I4). The Human Factor in Innovation. In: Dutta, S., Lanvin, B. and Wunsch-Vincent, S. (Eds.), The Global Innovation Index 2014, 69-74.

TEECE, D.J., Pisano, G., Shuen,A. (1997). Dynamic capabilities and strategic management. Strategic Management Journal, 18(7), 509-533. doi: http://dx.doi.org//0.1016/b978-0-75067088-3.50009-7

WIKLUND,J.(1999).The sustainability of the entrepreneurial orientation-performance relationship. Entrepreneurship Theory and Practice, 24(I), 37-48.

WIKLUND, J., Shepherd, D. (2005). Entrepreneurial orientation, and small business performance:a configurational approach. Journal of Business Venturing, 20(I), 7I-9I. doi:http://dx.doi.org/l0.1016/j.jbusvent.2004.01.00I

ZAHRA, S.A., George, G. (2002). Absorptive capacity: a review, reconceptualization, and extension. Academy of Management Review, 27(2) 185-203. doi:http://dx.doi. org/I 0.5465/amr.2002.6587995 